\title{
Determinant of Devidend Policy and Its Implications on Company Value (Study on Construction and Building Issuer Year 2014-2019)
}

\author{
Bambang Mulyana $^{1 *}$, Ahmad Badawi Saluy ${ }^{1}$, Karlina ${ }^{1 *}$
}

${ }^{1}$ Universitas Mercu Buana, Jakarta, Indonesia

DOI: $10.36348 / \mathrm{sb} .2021 . v 07 i 04.007$

| Received: 29.12.2020 | Accepted: 12.01.2021 | Published: 19.04.2021

*Corresponding author: Karlina

\section{Abstract}

The purpose of this research was to determine and analyze the effect of financial performance on devidend policy and its implications for corporate value in the construction and building industry sub-sector listed on the Indonesia Stock Exchange for the years 2014-2019. The population was 18 companies and sampling technique is purposive sampling, so that the sample in this study amounted to 8 companies. The data analysis technique used is multiple linear regression analysis with the help of Eviews Statistic application. The results of this research indicate that Cash Ratio has a negative not significant effect on DPR. DER has a positive not significant effect on DPR. ROA has a negative significant effect on DPR, while RTO has a negative not significant effect on DPR, and DPR has an effect negative not significant on Tobin's Q.

Keywords: Devidend Payout Ratio, Tobin's Q, Cash Ratio, Debt to Equity Ratio, Return On Assets dan Recevable TurnOver.

Copyright (C) 2021 The Author(s): This is an open-access article distributed under the terms of the Creative Commons Attribution 4.0 International License (CC BY-NC 4.0) which permits unrestricted use, distribution, and reproduction in any medium for non-commercial use provided the original author and source are credited.

\section{INTRODUCTION}

Massive infrastructure development in Indonesia is one of the factors in the increasing role of the construction sector to the country's economy. The role of the construction sector can be seen from the absorption of labor, investment, the number of infrastructure and building projects, reciprocal relationships with supporting sectors. The construction sector is even a facilitator in the movement and growth of goods and services. The construction sector also plays a role in supporting equitable development in other sectors, such as adequate road access for the transportation of goods and services, food security in each region, improvement of educational and health facilities, fulfillment of national electricity and energy needs, and increasing tourism attractiveness.

The form of investment that is often found in the capital market is stocks. A stock is a form of investment in which the investor buys a certain number of shares and nominal and in return for the purchase; the investor will receive a Devidend at the time specified by the company. For companies, devidend policy is very important because it concerns the small amount of profit that the company shares. The company's profit is the basic element of the devidend policy determined by the Devidend Payout Ratio. Profit is important for the company to maintain survival such as to fund the growth of the company, while investors expect the distribution of profits on the profit generated in the form of devidends.

The amount of devidend value depends on the profit earned by the company. The higher Devidend Payout Ratio will benefit investors, but for the company will weaken internal financial, because it reduces retained earnings. Conversely, if the Devidend Payout Ratio gets smaller it will harm the shareholders (investors) but the internal financial will be stronger.

Good financial performance will affect the devidends that will be received by shareholders because devidends are always based on current year net income and net income is a measure of the company's performance. Factors that influence the company's decision in determining the amount of profit to be distributed as devidends include: liquidity, solvency, profitability, and activity. Consideration of the size of a Devidend Payout Ratio is expected to be very closely related to financial performance, because a good financial performance of a company can be expected to 
determine the amount of Devidend Payout Ratio that is also in accordance with the expectations of shareholders.

This research is expected to provide information about how much liquidity; profitability, solvency, and activity affect the Devidend Payout Ratio and its implications for the company's value. This information is important because it is to know the ability of the company to share Devidends and to know how big the Devidend Payout Ratio is to construction and building companies. Devidend Payout Ratio is used to assess the company's growth as well as the Devidend Payout Ratio for investors as motivation in investing in a particular company.

Here is the average profit data on construction and building companies during 2014 to 2019: Figure 1, shows the profits of construction and building companies in 2014-2019 fluctuate with an increasing trend despite the ramps. (Source: idx.co.id)

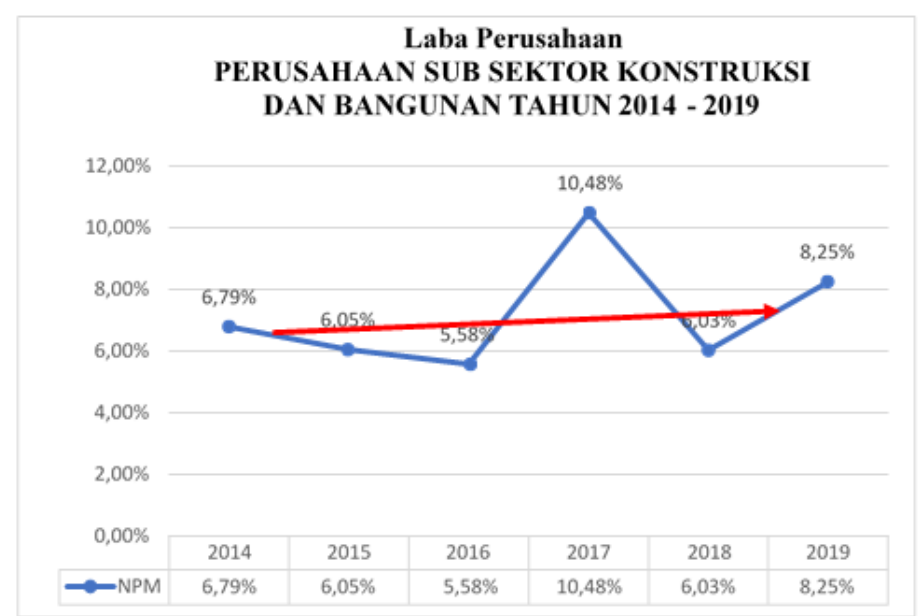

Fig-1: Average Profit of Construction and Building Sub-Sector Companies For the Period 2014-2019

In Figure 2, Devidend payments (Devidend Payout Ratio) during 2014 to 2019 appear to fluctuate with an increasing trend. (Source: idx.co.id)

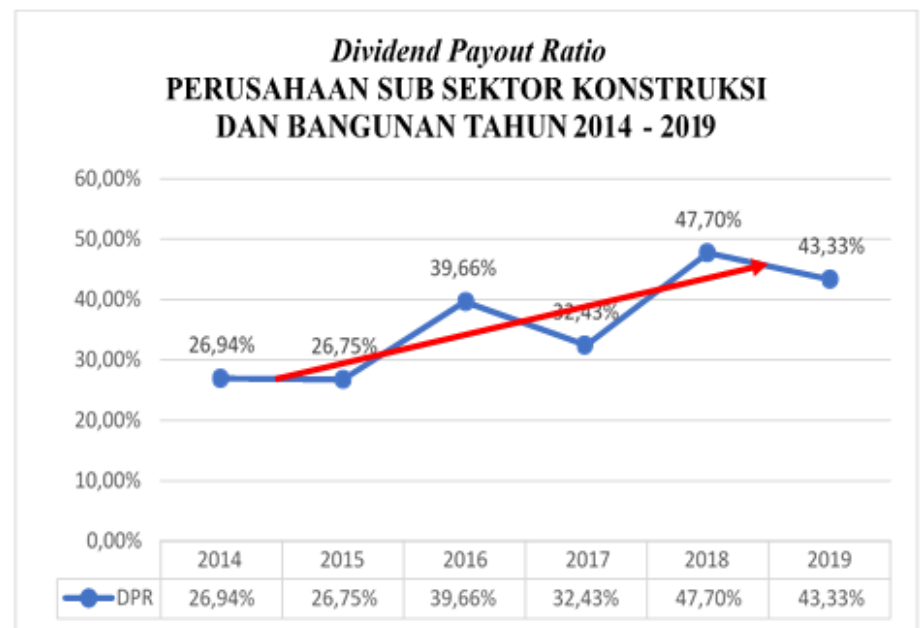

Fig-2: Average Devidend Payout Ratio of Construction and Building Sub-Sector Companies For the Period 2014-2019

Figure 3 shows that during 2014 - 2019 tends to decrease. (Source: idx.co.id). Looking at the phenomenon it is known that profits and Devidend payments are likely to rise but are not followed by an increase in the value of the company. Therefore, it is worth suspecting that there are factors that influence the decline in the value of the company.

\section{REVIEW OF LITERATURE The Company Value}

According to Husnan and Pudjiastuty [1] the value of the company is the price available paid by prospective buyers if the company is sold, the higher the value of the company the greater the prosperity that will be received by the owner of the company. The study used Tobin's Q to measure the company's value. 


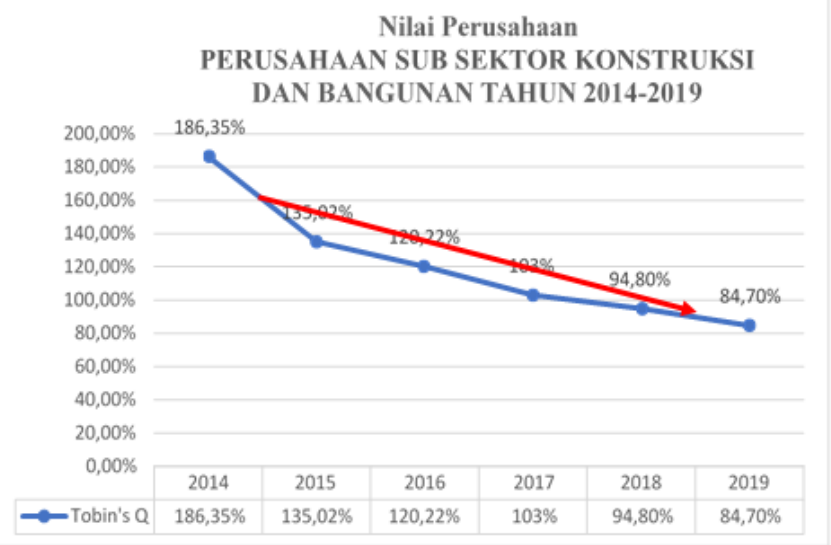

Fig-3: Average The Company Value of Construction and Building Sub-Sector Companies For the Period 2014-2019

\section{Devidend Policy}

It is a decision on whether the company's profit will be distributed to shareholders as Devidends or will be withheld in the form of retained earnings in order to finance investments in the future [2]. In this study, Devidend Payout Ratio was used as a proxy of Devidend policy.

\section{Liquidity Ratio}

It is a ratio that shows the relationship between cash and other assets of the company with current liabilities [3]. This study uses Cash Ratio to measure liquidity.

\section{Solvency Ratio}

Demonstrate the company's ability to meet its financial obligations if the company is liquidated, be it short-term or long-term debt [4]. In this study Debt to Equity Ratio is used to measure solvency.

\section{Profitability Ratio}

According to Hery [5] is a ratio measurement that aims to measure the level of effectiveness in running the company's operations. In this study, Return on Assets was used to measure profitability.

\section{Activity Ratio}

According to Fahmi [6] is a ratio that describes the extent to which a company uses its resources to support its activities, where the use of this activity is carried out to the maximum with the intention of obtaining maximum results. In this study Receivable TurnOver was used to measure activity.

\section{Conceptual Framework}

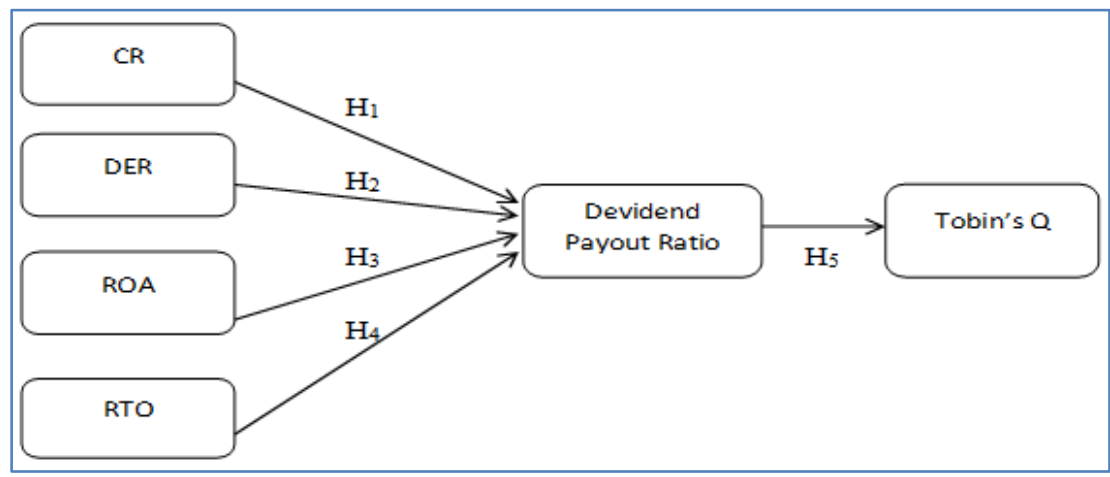

Fig-4: Theoretical Thought Frameworks

\section{RESEARCH HYPOTHESIS}

Based on the above frame of mind, the hypothesis of this research is:

1. Cash Ratio has a positive effect on Devidend Payout Ratio.

2. Debt to Equity Ratio has a negative effect on Devidend Payout Ratio.

3. Return On Assets has a positive effect on Devidend Payout Ratio.
4. Receivable TurnOver has a positive effect on Devidend Payout Ratio.

5. Devidend Payout Ratio has a negative effect on Tobin's Q.

\section{RESEARCH METHODOLOGY}

1. Subject and Object Research

The subjects in this study were 18 construction and building sub-sector companies listed on the Indonesia Stock Exchange in 2014-2019. While the 
Bambang Mulyana et al., Sch Bull, Apr, 2021; 7(4): 104-117

research objects are dependent variables (Devidend Payout Ratio, Tobin's Q) and independent variables (Cash Ratio, Debt to Equity Ratio, Return on Assets, Receivable TurnOver).

\section{Research Design}

This research uses a caesal research design. Causal research is a research conducted conclusive research that is causal, namely studying the causal relationship between free variables to bound variables.

\section{Operationalization Variable}

a) Tobin's Q

These are a number of figures from the comparison of equity market value plus total debt with total assets. The formula for calculating Tobin's Q is as follows:

$$
\text { Tobin's Q }=\frac{\text { Equity Market Value }+ \text { Total Liabilities }}{\text { Total Assets }}
$$

b) Devidend Payout Ratio (DPR)

Are a number of figures from the results of the comparison of Devidends with net income? The formula for calculating the Devidend Payout Ratio is as follows:

$$
\text { Devidend Payout Ratio }=\frac{\text { Devidend }}{\text { Net Income }} \times 100 \%
$$

\section{c) Cash Ratio}

It is a number of figures from the comparison between total cash plus cash equivalents and total current debt. The formula for calculating cash ratio is as follows:

$$
\text { Cash Ratio }=\frac{\text { Cash }+ \text { Cash Equivalents }}{\text { Current Liabilities }} \times 100 \%
$$

\section{d) Debt to Equity Ratio (DER)}

These are a number of figures from the comparison of total debt and total equity. The formula for calculating Debt to Equity Ratio is as follows:

$$
\mathrm{DER}=\frac{\text { Total Liabilities }}{\text { Total Equity }} \times 100 \%
$$

\section{e) Return On Assets (ROA)}

These are a number of figures from the comparison between net income and total assets. The formula for calculating Return on Assets is as follows:

$$
\text { Return on Assets }(\text { ROA })=\frac{\text { Net Income }}{\text { Total Assets }} \times 100 \%
$$

f) Receivable TurnOver (RTO)

That is a number of figures from the comparison between net sales and average trade receivables. The formula for calculating Receivable TurnOver is as follows:

$$
\text { Receivable TurnOver }=\frac{\text { Net Sales }}{\text { Average Receivables }} \times 100 \%
$$

\section{Samples and Methods Samples}

Sampling using purposive sampling method, with criteria:

1) Construction and Building Sub-Sector Company listed on Indonesia Stock Exchange in 2014-2019.

2) Construction and Building Sub-Sector Companies that distributed un breakup Devidends during 2014 2019.

3) Construction and Building Sub-Sector Companies that have financial data to calculate Tobin's Q during 2014-2019.

Based on these criteria, 8 companies were recorded as samples.

\section{Sample Data}

The data used are secondary data, quantitative, time series, cross section or panel data. Data collection techniques using documentation techniques

\section{DATA ANALYSIS METHODS}

The methods used in analyzing the data in this study are:

1. Descriptive Statistical Analysis

2. Stationary Test

3. Panel Data Regression Analysis

a) Common Effect Model

b) Fixed Effect Model

c) Random Effect Model

4. Model Selection Test

a) Chow Test

b) Hausman Test

c) Lagrange Multiplier Test

5. Panel Data Analysis

6. Hypothesis Test

a) Koefisien determinasi $\left(\mathrm{R}^{2}\right)$ Test

b) Statistical F Test

c) Statistical T Test 


\section{ANALYSIS AND DISCUSSION}

Table-1: Descriptive Statistical Analysis

\begin{tabular}{|l|c|c|c|c|c|c|}
\hline & TOBINS_Q & DPR & CR & DER & ROA & RTO \\
\hline Mean & 124.6110 & 34.84314 & 39.83182 & 226.5878 & 4.517153 & 5.866666 \\
\hline Median & 113.4070 & 23.72122 & 35.90891 & 216.3407 & 3.727925 & 3.890393 \\
\hline Maximum & 233.4237 & 141.7493 & 89.13653 & 511.3060 & 15.06319 & 27.56338 \\
\hline Minimum & 72.55084 & 6.374147 & 11.47731 & 68.85191 & 0.839305 & 0.923665 \\
\hline Std. Dev. & 39.42924 & 28.27252 & 18.30137 & 114.6224 & 2.869993 & 5.793906 \\
\hline Jarque-Bera & 10.43395 & 37.75988 & 4.196359 & 5.277580 & 64.64895 & 90.78642 \\
\hline Probability & 0.005424 & 0.000000 & 0.122680 & 0.071448 & 0.000000 & 0.000000 \\
\hline Sum & 5981.326 & 1672.471 & 1911.927 & 10876.21 & 216.8233 & 281.6000 \\
\hline Sum Sq. Dev. & 73069.26 & 37568.77 & 15742.19 & 617500.0 & 387.1325 & 1577.759 \\
\hline Observations & 48 & 48 & 48 & 48 & 48 & 48 \\
\hline
\end{tabular}

Source: Data Processed with Eviews 10

\section{Descriptive Variable Tobin's $Q$}

A minimum value of $72.55 \%$ obtained by PT Surya Semesta Internusa in 2018, while the maximum value of $233.42 \%$ was achieved by PT Nusa Raya Cipta in 2014 . The mean value is $124.61 \%$ which means that the average value range with the maximum value is wider than the average value range with the minimum value, so the company's value in construction and building sub-sector companies during 2014-2019 is mostly below average. The standard deviation value of $39.42 \%$ is less than the average value, indicating tobin's $\mathrm{Q}$ data in this study did not vary.

\section{Descriptive Variable Devidend Payout Ratio}

A minimum value of Devidend Payout Ratio of $6.37 \%$ was obtained by PT Surya Semesta Internusa in 2017, while the maximum value of $141.74 \%$ was achieved by PT Surya Semesta Internusa in 2018. Mean value of $34.84 \%$ indicates the range of average values with a minimum value wider than the range of average values with maximum value, then the data devidend payout ratio of construction and building sub-sector companies during 2014-2019 is mostly above average. The standard deviation value of $28.27 \%$ is less than the average value indicating that the Devidend Payout Ratio data is not diverse.

\section{Descriptive Variable Cash Ratio}

A minimum value of $11.47 \%$ was obtained by PT Adhi Karya in 2014, while the maximum value of $89.13 \%$ was achieved by PT Surya Semesta Internusa in 2018. The average value (mean) of $39.83 \%$ indicates the range of average values with a maximum value wider than the range of average values with a minimum value, meaning the Cash Ratio of construction and building sub-sector companies during 2014-2019 is mostly below average. The standard deviation value of $18.30 \%$, less than the average value shows the Cash Ratio data in this study is not diverse.

\section{Descriptive Variable Debt to Equity Ratio}

A minimum value of $68.85 \%$ was obtained by PT Surya Semesta Internusa in 2018, while the maximum value of $511.30 \%$ was achieved by PT Acset Indonusa in 2014. Mean value of $226.58 \%$ indicates the range of average values with a maximum value wider than the average value range with a minimum value, and then the Debt to Equity Ratio of construction and building sub-sector companies during 2014-2019 is mostly below average. The standard deviation value of $114.62 \%$, less than the average value, indicates that the Debt to Equity Ratio data does not vary.

\section{Descriptive Variable Return On Assets}

A minimum value of $0.83 \%$ was obtained by PT Waskita Karya in 2019, while the maximum value of $15.06 \%$ was achieved by PT Nusa Raya Cipta in 2014. The mean value of $4.51 \%$ represents the range of average values with a minimum value wider than the average value range with the maximum value, and then the Return on Assets of construction and building subsector companies during 2014-2019 are mostly above average. The standard deviation value is $2.86 \%$, less than the average value indicating the Return on Assets data does not vary.

\section{Descriptive Variable Receivable TurnOver}

A minimum value of $0.92 \%$ was obtained by PT Wijaya Karya in 2019, while the maximum value of $27.56 \%$ was achieved by PT Acset Indonusa in 2014. Mean value of $5.86 \%$, show the range of average values with a maximum value wider than the range of average values with a minimum value, then receivable turn over data on construction and building sub-sector companies during 2014-2019 is mostly below average. The standard deviation value is $5.79 \%$, less than the average value indicating the Receivable Turn Over data is not diverse.

\section{Stationary Test}

Table 2 shows that after 2st difference, Tobin's $Q$ variable has a probability value less than $\alpha 0.05$ then $\mathrm{H} 0$ is rejected which means that tobin's Q variable is stationary or not exposed to unit roots. 


\begin{tabular}{|c|c|c|c|}
\hline \multirow{2}{*}{\multicolumn{4}{|c|}{$\begin{array}{l}\text { Table } 2 \\
\qquad \text { Unir Root Test Tobin's } Q 2^{\text {nt }} \text { Difference } \\
\text { Null Hypothesis: D(TOBINS_Q,2) has a unit root } \\
\text { Exogenous: Constant } \\
\text { Lag Length: 4 (Avtomatic - based on SIC, maxlag=9) }\end{array}$}} \\
\hline & & & \\
\hline \multirow{4}{*}{\multicolumn{2}{|c|}{$\begin{array}{c}\text { Augmented Dickey-Futler test statistic } \\
\text { Test critical values: } \quad \begin{array}{c}1 \% \text { level } \\
5 \% \text { level } \\
10 \% \text { level }\end{array}\end{array}$}} & FStatistic & Prob.* \\
\hline & & -12.25407 & \multirow[t]{3}{*}{0.0000} \\
\hline & & -3.600987 & \\
\hline & & $\begin{array}{l}-2.935001 \\
-2.605836\end{array}$ & \\
\hline
\end{tabular}

Table 3 shows that after 1 st difference, devidend payout ratio variable has a probability value less than $\alpha 0.05$. Then $\mathrm{H} 0$ is rejected which means the variable Devidend Payout Ratio is stationary or not exposed to the roots of the unit.

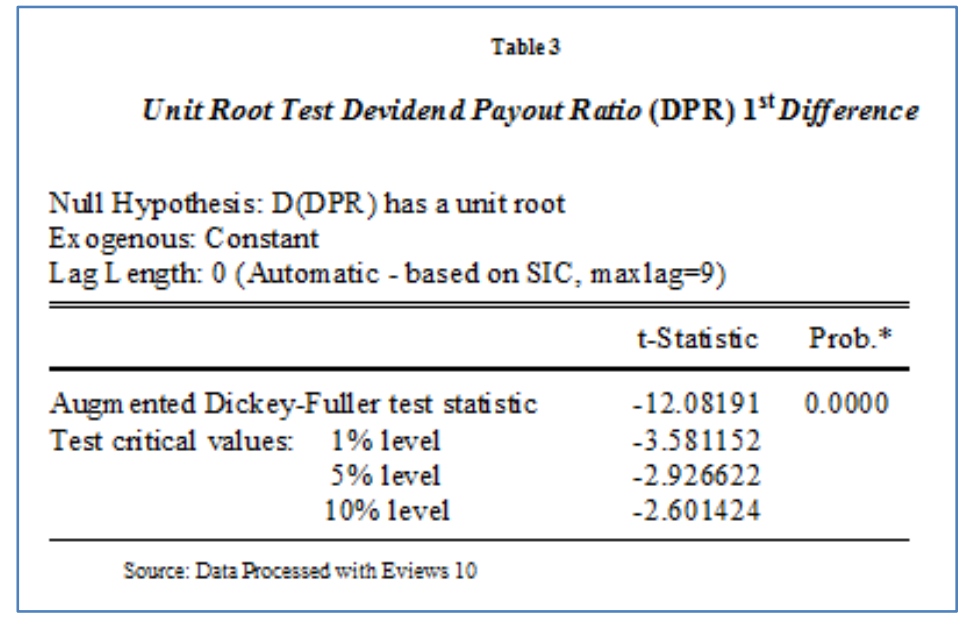

Table 4 shows that after 1 st difference, Cash Ratio variable has probability value less than $\alpha 0.05$, then $\mathrm{HO}$ is rejected which means the variable Cash
Ratio is stationary or not exposed to the roots of the unit.

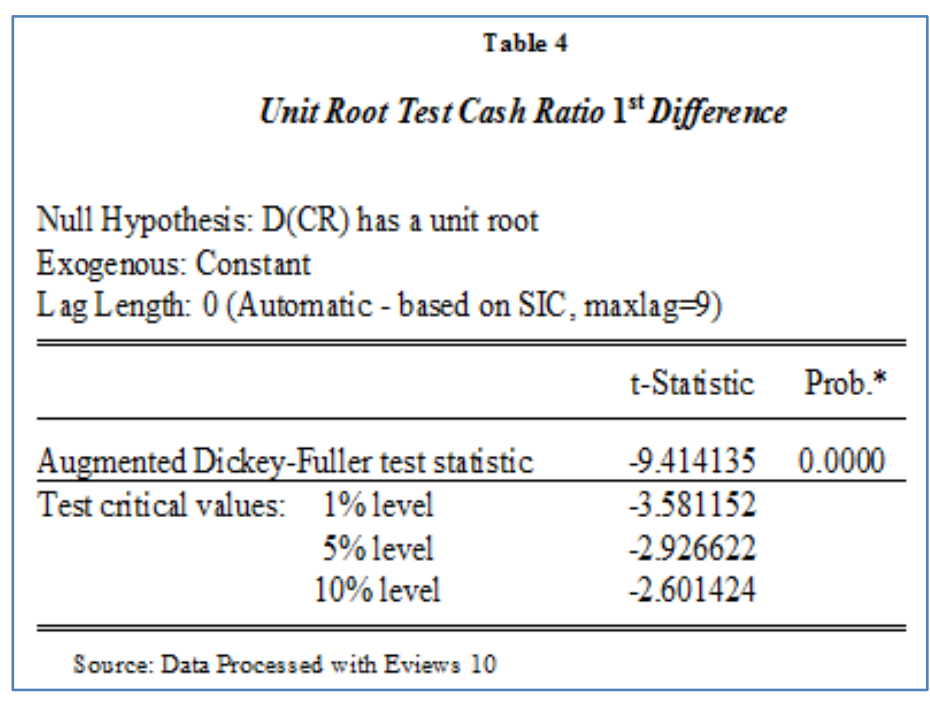


Table 5 shows that after 1 st difference, Debt to Equity Ratio variable has probability value less than $\alpha$
0.05 , then $\mathrm{H} 0$ rejected which means debt to equity ratio variable stationary or not exposed to unit roots.

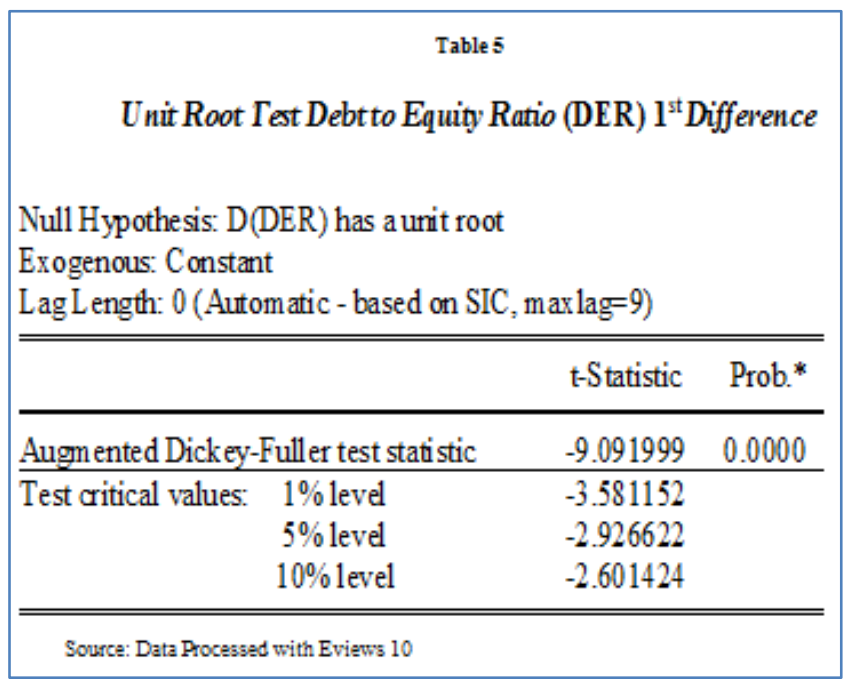

Table 6 shows that without the root unit test variable Return On Asset has a probability value less than $\alpha 0.05$, then $\mathrm{H} 0$ is rejected indicating that the return on asset variable is stationary or not exposed to the roots of the unit.

\begin{tabular}{|c|c|c|}
\hline \multirow{2}{*}{\multicolumn{3}{|c|}{$\begin{array}{l}\text { Table } 6 \\
\qquad \text { Unit Root Test Return On Assets (ROA) } \\
\text { Null Hypothesis: ROA has a unit root } \\
\text { Exogenous: Constant } \\
\text { Lag Length: } 0 \text { (Automatic - based on SIC, maxlag=9) }\end{array}$}} \\
\hline & & \\
\hline & t-Statistic & Prob.* \\
\hline Augmented Dickey-Fuller test statistic & -5.929801 & 0.0000 \\
\hline $\begin{array}{lc}\text { Test critical values: } & 1 \% \text { level } \\
& 5 \% \text { level } \\
10 \% \text { level }\end{array}$ & $\begin{array}{l}-3.577723 \\
-2.925169 \\
-2.600658\end{array}$ & \\
\hline
\end{tabular}

Table 7 shows that after 1 st difference, Receivable Turn Over variable has probability value less than $\alpha 0.05$, and then $\mathrm{H} 0$ rejected indicates that
Receivable TurnOver variable is stationary or not exposed to unit roots.

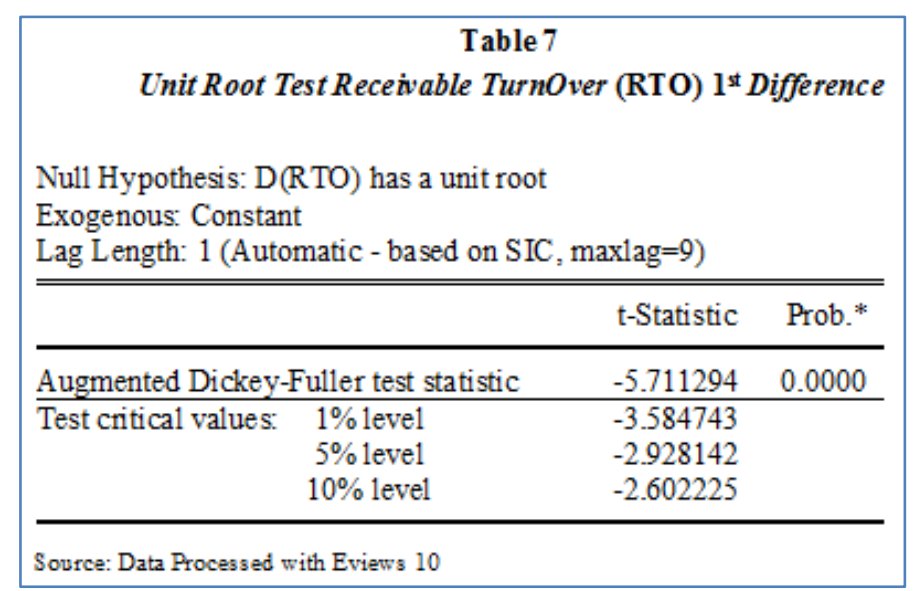




\section{Chow Test (Equation Model 1)}

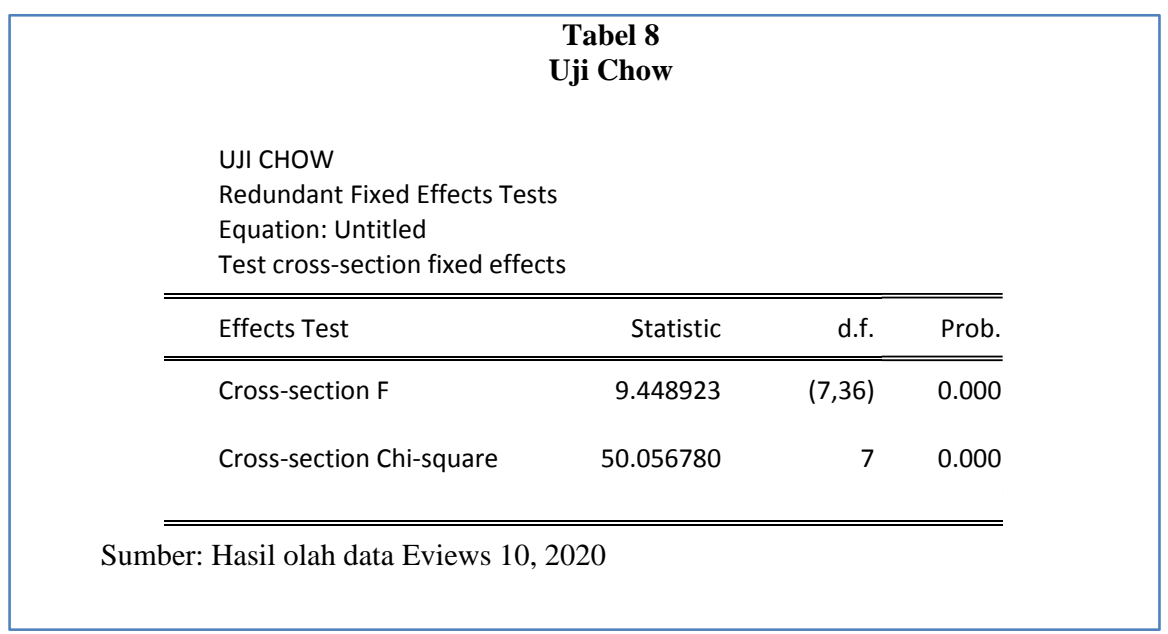

Based on the results of the test in Table 8 obtained Chi Square with a probability of $0.0000<$ 0.05 , meaning $\mathrm{H} 0$ is rejected and $\mathrm{H} 1$ are accepted. Then the appropriate model is Fixed Effect. Then the test is continued to Hausman test, to determine the best model between Fixed Effect and Random Effect.

\section{Hausman Test (Equation Model 1)}

\begin{tabular}{|c|c|c|c|}
\hline \multirow{2}{*}{\multicolumn{4}{|c|}{$\begin{array}{l}\text { Table } 9 \\
\text { Hausman Test } \\
\text { Correlated Random Effects - Hausm an Test } \\
\text { Equation: Untitled } \\
\text { Test cross-section random effects }\end{array}$}} \\
\hline & & & \\
\hline Test Summary & \multicolumn{2}{|c|}{$\begin{array}{l}\text { Chi-Sq. } \\
\text { Statistic Chi-Sq. df. }\end{array}$} & Prob. \\
\hline Cross-section random & 24.673322 & 4 & 0.0001 \\
\hline
\end{tabular}

Based on the test results in Table 9, crosssection probability values smaller than $\alpha 0.05$ were obtained, so H0 was rejected and H1 was accepted, meaning the appropriate model used was Fixed Effect.

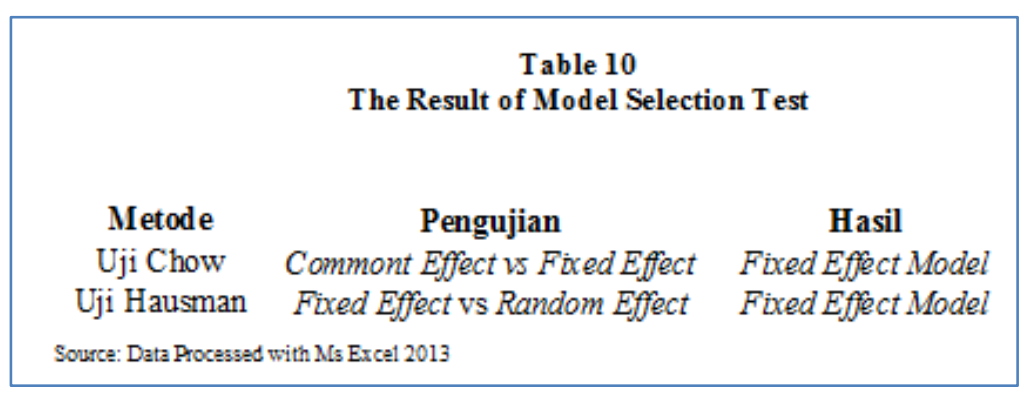

Based on Table 10 the most appropriate equation model to use is the Fixed Effect equation model. Thus, the analysis of the regression model of the following panel data will use the data in table 11 which is a table of Fixed Effect modeling results with equations: 


\begin{tabular}{|c|c|c|c|c|}
\hline \multirow{2}{*}{\multicolumn{5}{|c|}{$\begin{array}{l}\text { Dependent Variable: DPR } \\
\text { Method: Panel Least Squares } \\
\text { Date: } 09 / 14 / 20 \text { Time: } 20: 57 \\
\text { Sample: } 20142019 \\
\text { Periods included: } 6 \\
\text { Cross-sections included: } 8 \\
\text { Total panel (balanced) observations: } 48\end{array}$}} \\
\hline & & & & \\
\hline Variable & Coefficient & Std. Error & t-Statistic & Prob. \\
\hline $\begin{array}{c}\text { C } \\
\text { CR } \\
\text { DER } \\
\text { ROA } \\
\text { RTO }\end{array}$ & $\begin{array}{r}81.47653 \\
-0.379106 \\
0.001284 \\
-6.801664 \\
-0.187445\end{array}$ & $\begin{array}{l}23.96954 \\
0.304236 \\
0.049272 \\
1.495851 \\
0.744604\end{array}$ & $\begin{array}{r}3.399170 \\
-1.246090 \\
0.026057 \\
-4.547021 \\
-0.251737\end{array}$ & $\begin{array}{l}0.0017 \\
0.2208 \\
0.9794 \\
0.0001 \\
0.8027\end{array}$ \\
\hline \multicolumn{5}{|c|}{ Effects Specification } \\
\hline \multicolumn{5}{|c|}{ Cross-section fixed (dum my variables) } \\
\hline $\begin{array}{l}\text { R-squared } \\
\text { Adjusted R-squared } \\
\text { S.E. of regression } \\
\text { Sum squared resid } \\
\text { Log likelihood } \\
\text { F-statistic } \\
\text { Prob(F-statistic) }\end{array}$ & $\begin{array}{r}0.694903 \\
0.601678 \\
17.84356 \\
11462.13 \\
-199.5235 \\
7.454100 \\
0.000002\end{array}$ & $\begin{array}{l}\text { Mean depe } \\
\text { S.D. depen } \\
\text { Akaike inf } \\
\text { Schwarz } \mathrm{cr} \\
\text { Hannan-Q? } \\
\text { Durbin-Wa }\end{array}$ & $\begin{array}{l}\text { ndent var } \\
\text { dent var } \\
0 \text { criterion } \\
\text { citerion } \\
\text { ainn criter. } \\
\text { atson stat }\end{array}$ & $\begin{array}{l}34.84314 \\
28.27252 \\
8.813480 \\
9.281281 \\
8.990263 \\
2.143490\end{array}$ \\
\hline \multicolumn{5}{|c|}{ Source: Data Processed with Eviews 10} \\
\hline Devidend Payout Ra & $\begin{aligned} \operatorname{sio}(\mathrm{Y}) & =\boldsymbol{\alpha}-\boldsymbol{\beta} \boldsymbol{\chi} \\
& =81.476 \\
& 6.80166\end{aligned}$ & $\begin{array}{l}+\boldsymbol{\beta} 2 \chi^{2}-\boldsymbol{\beta 3} \\
-0.37910 \\
\mathrm{OA}-0.187\end{array}$ & $\begin{array}{l}-\beta 4 \chi 4+\mathrm{e} \\
\mathrm{R}+0.001284 \\
\text { RTO }\end{array}$ & DER - \\
\hline
\end{tabular}

\section{The equation can be interpreted as follows:}

1. Constant of 81.47653 indicates that if the value of CR, DER, ROA and RTO is equal to zero (0), then the Devidend Payout Ratio is 81.47653 .

2. Cash Ratio coefficient of 0.379106 with a negative sign that means that CR negatively affects dpr, where every increase in Cash Ratio by $1 \%$ will decrease Devidend Payout Ratio by $0.379106 \%$.

3. Der coefficient of 0.001284 with a positive sign means der has a positive effect on dpr, where every der increase of $1 \%$ will increase Devidend Payout Ratio by $0.001284 \%$.

4. Roa coefficient of 6.801664 with a negative sign which means ROA negatively affects dpr where each increase in ROA by $1 \%$ will decrease Devidend Payout Ratio by $6.801664 \%$.

5. Rto coefficient of 0.187445 with a negative sign interpreted by RTO negatively affects the Dpr where each rto increase of $1 \%$ will decrease the Devidend Payout Ratio by $0.187445 \%$.

\section{Hypothesis Test (Equation Model 1)}

\begin{tabular}{|lrll|}
\hline & \multicolumn{3}{c|}{ Table 12 } \\
R-squared & 0.694903 & Mean dependent var & 34.84314 \\
Adjusted R-squared & 0.601678 & SD. dependent var & 28.27252 \\
S.E. of regression & 17.84356 & Akaike info criterion & 8.813480 \\
Sum squared resid & 11462.13 & Schwarz criterion & 9.281281 \\
Log likelihood & -199.5235 & Hannan-Qvinn criter. & 8.990263 \\
F-statistic & 7.454100 & Durbin-Watson stat & 2.143490 \\
Prob(F-statistic) & 0.000002 & & \\
& & & \\
Source: Data Processed with Eviews 10 & \\
\hline
\end{tabular}


Bambang Mulyana et al., Sch Bull, Apr, 2021; 7(4): 104-117

\section{Koefisien determinasi $R^{2}$}

Based on Table 12, it is known that the ability of Cash Ratio, Debt to Equity Ratio, Return on Assets, and Receivable Turn Over in explaining Devidend Payout Ratio of $60.1678 \%$ is quite strong. The remaining $39.8322 \%$ is explained by other variables such as Inventory TurnOver, Current Ratio, Return on Equity, and others.

\section{Statistical F Test}

Distribution table $\mathrm{F}$ is searched $\alpha=5 \%$ with df $1=4$, df $2=48$ obtained by 2.58 . Table 12 represents a statistical F-value of 7.454100 greater than F-table 2.58 and a significance value of 0.000002 less than $\alpha$ of 0.05 so that $\mathrm{H} 0$ is rejected and $\mathrm{H} 1$ is accepted. Therefore, it is interpreted that Cash Ratio, Debt Equity Ratio, Return On Assets, and Receivable Turn Over have a significant effect on Devidend Payout Ratio and regression model worthy of use in this study and able to explain the influence of independent variables on dependent variables.

\section{Statistical T Test}

\begin{tabular}{|crrrr|}
\hline \multicolumn{9}{c}{ Table 13 } \\
Statistical T T est & \\
& & & \\
& & & & \\
Variable & Coefficient & Std. Error & t-Statistic & Prob. \\
\hline C & 81.47653 & 23.96954 & 3.399170 & 0.0017 \\
CR & -0.379106 & 0.304236 & -1.246090 & 0.2208 \\
DER & 0.001284 & 0.049272 & 0.026057 & 0.9794 \\
ROA & -6.801664 & 1.495851 & -4.547021 & 0.0001 \\
RTO & -0.187445 & 0.744604 & -0.251737 & 0.8027 \\
\hline Source: Data Processed with Eviews 10 & & & \\
\hline
\end{tabular}

Table 13 shows that

a) Cash Ratio coefficient value of -0.379106 with tstatistic value of -1.246090 less than $t$-table of 2.01669. At the significance level of $\alpha 5 \%$ and the probability value of 0.2208 is greater than the significance level of 0.05 Then $\mathrm{HO}$ is accepted and $\mathrm{H} 1$ is rejected, so it can be interpreted that the Cash Ratio has a negative and insignificant effect on the Devidend Payout Ratio.

b) The coefficient of Debt to Equity Ratio is 0.001284 with a t-statistic value of 0.026057 less than the t-table of 2.01669. At the level of $\alpha$ significance of $5 \%$ and the probability value of 0.9794 is greater than the significance level of 0.05. So HO is accepted and H1 is rejected, so it can be interpreted that Debt to Equity Ratio has a positive and insignificant effect on Devidend Payout Ratio. c) The coefficient of Return on Asset -6.801664 with a probability value of 0.0001 less than the significance level of 0.05 . Thus $\mathrm{H} 0$ is rejected and $\mathrm{H} 1$ is accepted so that it can be interpreted that Return on Assets has a negative and significant effect on the Devidend Payout Ratio.

d) The coefficient of Receivable Turn Over 0.187445 with a t-statistic value of -0.251737 is less than the table t-table of 2.01669. At the level of significance $\alpha 5 \%$ and the probability value of 0.8027 is less than the significance level, H0 is received and $\mathrm{H} 1$ is rejected. Thus Receivable Turn Over has an insignificant negative effect on Devidend Payout Ratio.

\section{Chow Test (Equation Model 2)}

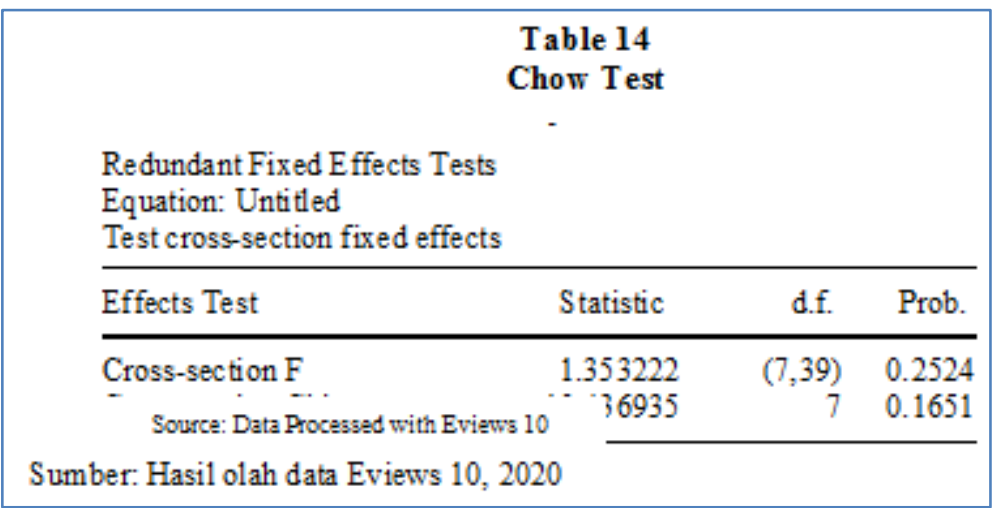


Based on the results of the test in Table 14 obtained Chi square with a probability of $0.1651>0.05$ which means H0 is received. Chow's test results received $\mathrm{H} 0$ and rejected $\mathrm{H} 1$, so the appropriate model analysis is common effect. Then the test is continued to
Hausman test, to determine the best model between Fixed Effect and Random Effect.

Hausman Test (Equation Model 2)

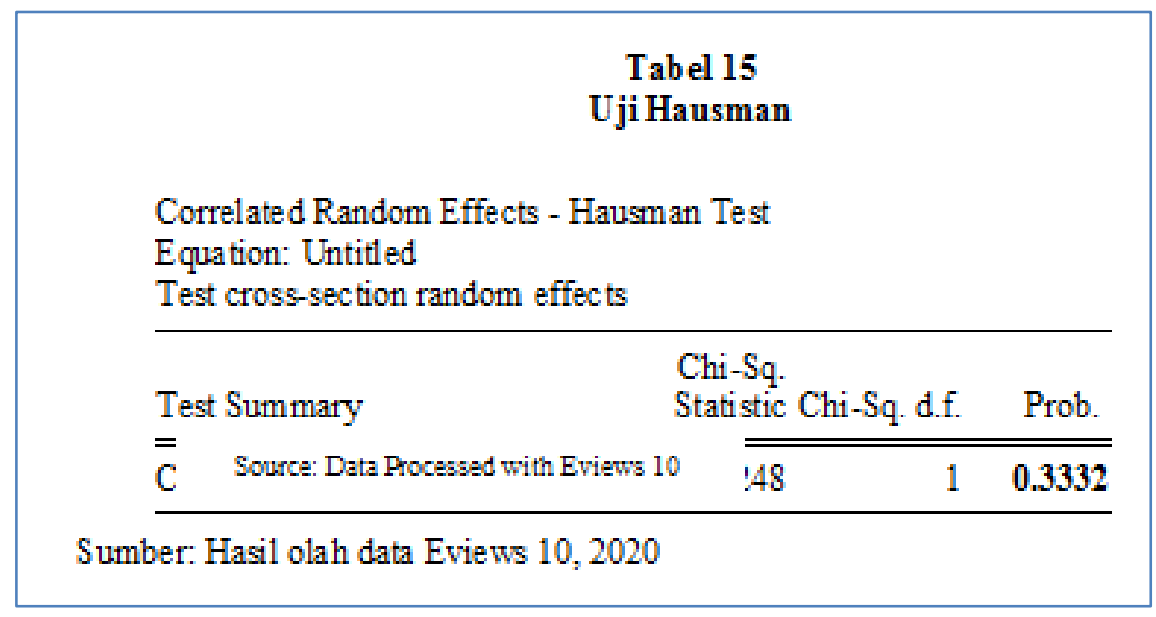

Based on the test results in table 15 , crosssection probability values smaller than $\alpha 0.05$ to $\mathrm{H} 0$ are accepted, which means the right model to use is Random Effect.
Lagrange Multiplier Test (Equation Model 2)

\begin{tabular}{|c|c|c|c|}
\hline \multicolumn{4}{|c|}{$\begin{array}{l}\text { Lagrange multiplier (LM) test for panel data } \\
\text { Date: 09/15/20 Time: } 21: 09 \\
\text { Sample: } 20142019 \\
\text { Total panel observations: } 48 \\
\text { Probability in } 0\end{array}$} \\
\hline $\begin{array}{l}\text { Null (no rand. } \\
\text { effect) } \\
\text { Altemative }\end{array}$ & $\begin{array}{l}\text { Cross-section } \\
\text { One-sided }\end{array}$ & $\begin{array}{l}\text { Period } \\
\text { One-sided }\end{array}$ & Both \\
\hline Brevsch-Pagan & $\begin{array}{l}0.057696 \\
(0.8102)\end{array}$ & $\begin{array}{l}69.81657 \\
(0.0000)\end{array}$ & $\begin{array}{l}69.87427 \\
(0.0000)\end{array}$ \\
\hline Honda & $\begin{array}{l}0.240200 \\
(0.4051)\end{array}$ & $\begin{array}{l}8.355631 \\
(0.0000)\end{array}$ & $\begin{array}{l}6.078171 \\
(0.0000)\end{array}$ \\
\hline King -Wv & $\begin{array}{l}0.240200 \\
(0.4051)\end{array}$ & $\begin{array}{l}8.355631 \\
(0.0000)\end{array}$ & $\begin{array}{l}6.536768 \\
(0.0000)\end{array}$ \\
\hline GHM & -. & - & $\begin{array}{l}69.87427 \\
(0.0000)\end{array}$ \\
\hline Source: Data Proce & with Eviews 10 & 1 & \\
\hline
\end{tabular}

From the test results in Table 16 obtained the calculated LM value is 0.8102 greater than $\alpha 0.05$ which means the LM value calculates > Chi-Squared table. Then the selected model is common effect. 


\begin{tabular}{|ccc|}
\hline & \multicolumn{1}{c|}{ Table 17 } & \\
& The Result of Model Selection Test \\
Metode & Pengujian & Hasil \\
Uji Chow & Common Effect vs & Common Effect \\
Uji Hausman & Fixed Effect & Model \\
& Fixed Effect vs & Random Effect \\
Uji Lagrange & Randbm Effect & Model \\
Miltiplier & Common Effect vs & Common Effect \\
& Random Effect & Model \\
& & \\
\hline Source: Data Processed with Ms Excel 2013 & \\
\hline
\end{tabular}

Table 17 shows the most appropriate equation model for researchers to use is the Common Effect equation model.

\begin{tabular}{|c|c|c|c|}
\hline \multicolumn{4}{|c|}{$\begin{array}{l}\text { Table 18 } \\
\qquad \text { Common E ffect Method } \\
\text { Dependent Variable: TOBINS_Q } \\
\text { Method: Panel Least Squares } \\
\text { Date: } 09 / 15 / 20 \text { Time: } 20: 53 \\
\text { Sample: } 20142019 \\
\text { Periods included: } 6 \\
\text { Cross-sections included: } 8 \\
\text { Total panel (balanced) observations: } 48\end{array}$} \\
\hline Variable & Coefficient & Std. Error t-Statistic & Prob. \\
\hline $\begin{array}{c}\mathrm{C} \\
\mathrm{DPR}\end{array}$ & $\begin{array}{r}132.0950 \\
-0.214793\end{array}$ & $\begin{array}{rr}9.078649 & 14.55008 \\
0.203171 & -1.057205\end{array}$ & $\begin{array}{l}0.0000 \\
0.2959\end{array}$ \\
\hline R-squared & 0.023721 & Mean dependent var & 124.6110 \\
\hline $\begin{array}{l}\text { Adjusted R-squared } \\
\text { SE. of regression } \\
\text { Sum squared resid } \\
\text { Log likelihood } \\
\text { F-sta tistic } \\
\text { Prob(F-statistic) }\end{array}$ & $\begin{array}{r}0.002498 \\
39.37997 \\
71335.98 \\
-243.4040 \\
1.117682 \\
0.295939\end{array}$ & $\begin{array}{l}\text { SD. dependent var } \\
\text { Akaike info criterion } \\
\text { Schwarz criterion } \\
\text { Hannan-Quinn criter. } \\
\text { Durbin-Watson stat }\end{array}$ & $\begin{array}{l}39.42924 \\
10.22517 \\
10.30313 \\
10.25463 \\
0.595530\end{array}$ \\
\hline
\end{tabular}

From the above results obtained Common Effect equations are:

$$
\text { Tobin's } Q \quad=132.0950-0.214793 \mathrm{DPR}
$$

With the achievements as follows:

1. Constant of 132.0950 means that if devidend payout ratio is equal to zero (0), then Tobin's $Q$ is 132.0950 .

2. The Coefficient of Devidend Payout Ratio is 0.214793 with a negative sign which means that the Dpr has a negative effect on the value of the company, where each increase in the Devidend Payout Ratio by $1 \%$ will decrease the value of the company (Tobin's Q) by $0.214793 \%$.

\section{Hypothesis Test (Equation Model 2)}

1. Koefisien determinasi $R^{2}$

Based on table 18, it is known that the ability of Devidend Payout Ratio to explain Tobin's Q behavior is very small at $2.3721 \%$, while the remaining $97.6279 \%$ is explained by other variables outside this research model.

\section{Statistical F Test}

Distribution table $\mathrm{F}$ is searched $\alpha=5 \%$ with df $1=1$, df $2=48$ obtained by 4.05 . In the F-statistical test above, the result of F-statistical value is 1.117682 less than F-table 4.05 with probability value F-statistic 1.117682. Because the significance value is greater than $\alpha 0.05$ then $\mathrm{H} 0$ is accepted. Thus it can be interpreted 
that devidend payout ratio has no significant effect on Tobin's Q.

\section{Statistical T Test}

Based on table 18, it can be found that the coefficient of Devidend Payout Ratio is -0.214793 and tstatistic value is -1.057205 less than t-table of 2.01298 . At the level of significance $\alpha 0.05$ and the probability value of 0.2959 is greater than the significance level, H0 is received and $\mathrm{H} 1$ is rejected. So it can be interpreted that Devidend Payout Ratio has a negative and insignificant effect on Tobin's Q.

\section{DISCUSSION}

\section{Effect of Cash Ratio on Devidend Payout Ratio}

Based on table 18, it can be noted that Cash Ratio negatively and insignificantly affects Devidend Payout Ratio with a coefficient of -0.379106 . This means that the available cash is first used to pay obligations to creditors so that shareholders only receive the remaining cash that is relatively small. In Brigham's opinion, the Devidend policy is influenced by the availability of cash, if an increase in cash occurs then by some calculation the company will increase its Devidend payments. Thus the results of this study are not in line with the opinions of Brigham and Houston. The results of this study are in line with research conducted by Affandi, Sunarko and Yunanto [7] which found that Cash Ratio has a negative and insignificant influence on Devidend Payout Ratio (DPR).

\section{Effect of Debt to Equity Ratio on Devidend Payout Ratio}

Based on table 18, it can be noted that Debt to Equity Ratio has a positive and insignificant effect on Devidend Payout Ratio with a coefficient of 0.001284 . It is commonly known that project financing undertaken by construction and building sub-sector companies is financed with debt from creditors. This means that the more projects the greater the profit potential will be obtained. So with a high profit, it will lead to an increase in the company's ability to distribute Devidends to shareholders. The greater the Debt to Equity Ratio, the greater the loan capital so that it will cause the greater the debt burden (interest expense) that must be borne by the company. The greater the debt burden of the company, the amount of profit distributed as Devidends will be reduced. The results of this study are in line with research conducted by Perpatih [8]. However, the results of this study are not in line with research conducted by Purba, Sheren, Valent, Angeline [19].

\section{Effect of Return On Assets on Devidend Payout Ratio}

Based on table 18, it can be found that Return on Assets has a negative and significant effect on Devidend Payout Ratio with a coefficient of -6.801664 . Return on Assets is a measure of the company's effectiveness in generating profits by utilizing fixed assets used for operations. The smaller the Return on Assets shows the company's poor performance, because the smaller the return on investment. Returns that will be received by investors can be Devidend income. Companies that have a small level of profit tend to have large debts. The results of this study are in line with research conducted by Nofrita [10]. However, the results of this study are not in line with Nurhayati's research [11].

\section{Effect of Receivable Turn Over on Devidend Payout Ratio}

Based on table 18, it can be noted that Receivable TurnOver negatively and significantly affects Devidend Payout Ratio with coefficient of -0.187445 . This means that the lower the Receivable Turn Over value will have a bad impact on the Value of Devidend Payout Ratio. This happens because the company is less able to manage the turnover of receivable levels quickly so that the production and operational processes do not run smoothly, so that sales decrease, with the decrease in sales will result in low profit. With low profit, it will cause a decrease in the company to distribute Devidends to shareholders. The results of this study are not in line with research conducted by Affandi, Sunarko and Yunanto [7].

\section{Effect of Devidend Payout Ratio on Tobin's $Q$}

Based on table 18, it can be found that Devidend Payout Ratio negatively and insignificantly affects Tobin's Q with a coefficient of -0.214793 . This means that any increase in the Devidend Payout Ratio by $1 \%$ will decrease the company's value (Tobin's Q) by 0.187445 but the decrease in the company's value (Tobin's Q) is not significant.

Based on this, it can be interpreted that the increase in the value of devidend payout ratio that causes a decrease in market perception of the value of the company although not significant may be because the market or investors prefer any profit reinvested in a larger portion to increase production capacity. If the company makes an investment, the market gives a positive sentiment to the value of the company, and it becomes a positive issue for the company in the market that allows the share price to increase. With the rising share price, investors will get a profit in the form of capital gains. So it is understandable if the increase in Devidend Payout Ratio will decrease the value of the company.

Modigliani and Miller argue the value of a company is not determined by the size of its small Devidend Payout Ratio, but is determined by its net profit before tax and business risk. Thus it is suspected that companies that have a large profit will not necessarily provide a large Devidend because it is likely that the company will use its profit results as additional capital to play the company's activities. The results of 
this study are in line with the research of Bernandhi and Muid [12], Kodir [13], which found that the variable Devidend Payout Ratio has no significant effect on the value of the company.

\section{PENUTUP}

\section{CONCLUSION}

1. Cash Ratio negatively and insignificant effect on Devidend Payout Ratio.

2. Debt to Equity Ratio has a positive and insignificant effect on Devidend Payout Ratio.

3. Return on Assets has a negative and significant effect on Devidend Payout Ratio.

4. Receivable Turn Over has a negative and insignificant effect on the Devidend Payout Ratio.

5. Devidend Payout Ratio negatively and insignificantly affects Tobin's Q.

\section{REFERENCES}

1. Husnan, S. (2002). Manajemen Keuangan Teori Dan Praktek, Yayasan Badan Penerbit Gajah Mada Yogyakarta, Yogyakarta.

2. Agus, S. (2008). Manajemen Keuangan Teori dan Aplikasinya. Edisi Empat. Yogyakarta: BPFE.

3. Brigham, E.F., dan, Joul, F. Houston. (2014). "Dasar-dasar ManajemenKeuangan". Jakarta: Salemba Empat.

4. Munawir. (2007). Analisis Laporan Keuangan. Yogyakarta: Edisi Empat, Liberty.

5. Hery. (2015). Analisis Laporan Keuangan. Edisi 1. Yogyakarta: Center for Academic Publishing Services.

6. Fahmi, I. (2013). “Analisis Laporan Keuangan". Bandung: Alfabeta.

7. Affandi, F., Sunarko, B., \& Yunanto, A. (2018). The Impact of Cash Ratio, Debt to Equity Ratio,
Receivables Turnover, Net Profit Margin, Return On Equity, and Institutional Ownership To Devidend Payout Ratio. Journal of Research in Management, 1(4), 1-11.

8. Janifairus, J. B., Hidayat, R., \& Husaini, A. (2013). Pengaruh Return On Asset, Debt To Equity Ratio, Assets Growth, Dan Cash Ratio Terhadap Dividend Payout Ratio (Studi pada Perusahaan Manufaktur Barang Konsumsi yang Listing di Bursa Efek Indonesia Periode 2008-2010). Jurnal Administrasi Bisnis, 1(1), 161-169.

9. Widati, L. W. (2015). Pengaruh current ratio, debt to equity ratio, dan return on equity, untuk memprediksi kondisi financial distress.

10. Nofrita, R. (2013). Pengaruh Profitabilitas terhadap Nilai Perusahaan dengan Kebijakan Deviden sebagai Variabel Intervening (Studi Empiris pada Perusahaan Manufaktur yang Terdaftar di BEI). Jurnal Akuntansi, 1(1).

11. Nurhayati, M. (2013). Profitabilitas, likuiditas dan ukuran perusahaan pengaruhnya terhadap kebijakan dividen dan nilai perusahaan sektor non jasa. Jurnal Keuangan \& Bisnis Program Studi Magister Manajemen Sekolah Tinggi Ilmu Ekonomi Harapan, 5(2), 144-153.

12. Bernandhi, R., \& Muid, D. (2014). Pengaruh kepemilikan manajerial, kepemilikan institusional, kebijakan dividen, leverage, dan ukuran perusahaan terhadap nilai perusahaan. Diponegoro Journal of Accounting, 3(1), 177-191.

13. Kodir, M. (2013). Pengaruh Faktor-Faktor Fundamental Perusahaan, Kurs Dan Tingkat Bunga Terhadap Nilai Perusahaan Pada Perusahaan Manufaktur Yang Terdaftar Di Bursa Efek Indonesia. JBIMA (Jurnal Bisnis dan Manajemen), 1(1), 56-65. 